\title{
CHALLENGES (OBSTACLES) IN REACHING LEADERSHIP POSITIONS - EXPERIENCES OF WOMEN PROFESSORS AT NOVI SAD UNIVERSITY SERBIA
}

\author{
MARIJANA MIŠIĆ ANDRIĆ \\ Centre for Gender Studies, University of Novi Sad, \\ Dr Zorana Đinćića 1, 21000 Novi Sad, Serbia \\ mima.misic@gmail.com \\ SLOBODANKA MARKOV \\ University of Novi Sad \\ Trg Dositeja Obradovića 3, 21000 Novi Sad, Serbia \\ slobodanka.markov@gmail.com
}

\begin{abstract}
Underrepresentation of women in leadership positions in universities is a phenomenon present in most countries of the world, with some significant differences. In our work we focused on obstacles that women professors in Novi Sad University (Serbia) faced in reaching leadership positions. Analysis is based on qualitative research using a semi structured interview, statistical data and selected secondary sources. Obstacles, mentorship and networking have been researched from an idiographic perspective (reflection and the personal experience of the women at Novi Sad University). Results indicate a significant underrepresentation of women in leadership positions at Novi Sad University. Findings point to a general pattern: the more power and authority the leadership position holds, the scarcer the number of women participating in it. According to interviewees' statements the patriarchal value system makes the leadership positions difficult to attain for women. Interview analysis also suggests additional limiting factors, such as lack of mentorship and inadequate networking, acting as inhibitors in reaching leadership positions.
\end{abstract}

Keywords: gender equality, leadership, mentoring, networking, university, women.

\section{Introduction}

In contemporary society human resources are among the most important values. Therefore, it is imperative for all institutions, especially those of higher education, to develop and implement policies and procedures guiding and supporting employees in their career 
development. For many countries implementation of career development strategies and programmes is proving to be a challenge because of gender inequality.

UNDP (2011) data, the Female FTSE Report (2010) (Vinnicombe et al. 2010) and other statistical sources and research data indicate that the rates of women's presence in leadership positions is very low in different business sectors, on a global scale, despite attempts to implement various strategies and policies for women's career development (Bagilhole and White 2011; Powell 2010; Davidson and Burke 2011). Women make up $40 \%$ of the global work force and the teaching profession is almost completely feminized and yet women are underrepresented in leaderships positions in education (higher, in particular) outlining a pattern according to which "women teach and men lead" (Vrcelj 2014:25).

In the context of European integration efforts, Serbia has initiated over the last two decades the process of incorporating gender equality as a principle of universal human rights and one of the key requirements in establishing democracy, social peace and justice. Data reveal that despite the well-defined legal framework and public policies the level of gender equality is lower (40.6\% for 2014) than the average for the European Union (52.9\% for 2012) (Babović 2016:33). Data provided by the Statistical Office of the Republic of Serbia for 2013 show that men hold $66.46 \%$ of leadership positions and women $33.54 \%$ in different business sectors, pointing to a massive underrepresentation of women. This trend is also visible in higher education as indicated by several studies (Markov 2006; Pejatović and Orlović-Lovren 2015). It is particularly important to note that with the rise of authority and power in a leadership position the representation of women is even further diminished (Markov 2006:266).

The goal of this study is to explore the very cause of (under)representation of women in leadership positions in higher education institutions at the University of Novi Sad (hereafter University) with a special focus on mentoring and networking.

In the following sections of the paper we discuss the theoretical framework of mentorship and networking and the methodology used, followed by the data analysis and a discussion of the findings; finally, we present our conclusions, the implications and limitations of our research, indicating possible directions for future research.

\section{Literature Review}

Women with leadership potential in different business sectors, including higher education, face different obstacles in their professional career as indicated by numerous studies (Bagilhole and White 2011; Frank Fox et al. 2011; Pereira 2007; Vrcelj 2014; PrijićSamardžija, Avelini Holjevac and Turk 2009). In this paper we focus on mentoring and 
networking as important challenges, i.e. obstacles, for women in reaching leadership positions at the University. We understand the term "challenges" as situations in which women professors face obstacles, including the demanding circumstances that make it hard for them to reach leadership positions.

\section{Mentoring}

Mentoring in higher education includes socialization of employees in the spirit of the institutional culture and support for career development, or according to Quinn's definition: "Mentoring is a voluntary learning relationship that offers personal development for the mentee" (2012:3). According to the same source, there are three types of mentoring: formal, informal and peer mentoring (Quinn 2012:4).

Formal mentoring represents a specially designed mentoring programme developed and implemented by the university. Within the programme each mentor is listed alongside with the place, time and duration of the mentoring programme. This is a method meant to reinforce informal partnerships that have always been present in the workplace and mostly available for men, although there have been some efforts lately to make them more accessible to women, too (de Vries and Webb 2005:574).

Informal mentoring represents a direct relationship of an older and a younger member of the university meant to help the latter acquire relevant skills so as to be able to reach influential individuals in their profession who exert a direct influence on their carreer development.

Peer mentoring is non-hierarchical, mentor and mentee having an equal relationship. This type of mentoring facilitates communication and leads to better information exchange and emotional support of the mentee. It is the most frequent type of mentoring to be found in an academic environment.

Generally speaking, mentoring has numerous advantages and benefits for both mentor and mentee. The mentor directs the mentee in their career planning, provides psychological support and encourages awareness-raising. Mentoring leads to institutionalized recognition for the mentor, expands their competencies and also provides personal gratification.

Research shows that women face more obstacles in their professional advancement and that mentoring proves more of a problem for women than for men (McDowall-Long 2004:521; Tharenou 2005:78). Mentoring is particularly important for women with less professional experience since for them the substantial experience and knowledge of the mentor provides the encouragement necessary for their further development or improvement of their leadership 
potential (Abalkhail and Allan 2015:156). Women are very often reluctant to seek out a mentor due to fear of being misunderstood either by the mentor or by other employees in the organization. As a result, "it is more difficult for women to seek and get help from a mentor than it is for men." (Acker 2008:292). Some studies indicate that women find it easier to seek other women as mentors in their career development as they feel more comfortable, both socially and professionally. (Tharenou 2005; McDowall-Long 2004).

On the other hand, several authors demonstrate that lack of mentoring is a factor that hinders women's professional advancement and their access to leadership positions (Airini et al. 2011; Peters 2011; Blackwood and Brown-Welty 2011). In an academic context, mentoring creates great opportunities for women to network, to improve research skills and further understanding of their role in the organizational structure (Driscoll, Parkes, Tilley-Lubbs, Brill and Bannister 2009:6). Such findings are in line with Kanter's organizational structural theory (1977) (Albalkhail and Allan 2015:155) which suggests that career advancement is influenced by the position of the individual within the organization as well as by opportunities for networking, mentoring and peer support. As women traditionally belong to the groups with no power, they find themselves at a disadvantage when it comes to availability of organizational resources, of social networking and mentoring (Albalkhail and Allan 2015:155).

\section{Networking}

The old saying 'It is not what you know, but who you know' has a host of implications when it comes to career development strategies and policies.

Although the literature offers a plethora of definitions for networking we have chosen to define it as human behaviour that relates to developing, maintaining, changing and abandoning relations with others (Benschop 2009:221). Networking also determines activities among people as they try to develop relationships with those that could contribute to their career development (Singh et al. 2006:459). According to Terhi at al. (2017:270) networking is made up of connections and relations between academic staff members that are not primarily focused on the job but represent personal relations (friendship, partnership). Networking is a technique that triggers information exchange, opportunities and sources within and outside an organization (Hassan et al. 2017:4).

Networking can be tackled from two perspectives: formal and informal. Formal networking represents the relation between employees based on their position in the organization, where they share professional knowledge and other elements that relate to their career. Informal networking is based on personal awareness of potential and competencies, 
provided that potential is sufficient for success and higher ranking in the organization (Durbin and Tomlinson 2010: 625).

Establishing effective relationships between younger and older staff members is instrumental to career development (Durbin and Tomlinson 2010:625). Networking provides opportunities for career development and access to the highest leadership positions in organizations (Ismail and Rasdi 2007:154). Many studies point to a positive relation between networking and publishing academic papers in high impact factor journals, especially when we consider that publishing is a most important requirement for career advancement in higher education (Warner, Carapinha, Weber, Hill and Reede 2016:6). Furthermore, networking with others facilitates the acquisition of new knowledge, provides professional references and is a source of new information. (Hassan et al. 2017:5).

Numerous research studies centre on the gender aspects of the structure and success of networking (Durbin and Tomlinson 2010; Forret and Dougherty 2004). Lack of or weak networking has a negative effect on women's professional growth (Linehan and Scullion, 2001:825), and it is one of the most frequent reasons for the underrepresentation of women in leadership positions in higher education and in general. As severe constraints are placed on their time due to family and domestic obligations, women tend to use their networks for psychological and emotional support rather than for career development whereas men use their networks for self-promotion and for increasing their visibility in the organization (Tonge 2008:486). According to more recent research, networking has a significant positive effect on women academics' career advancement and this is primarily reflected in positive changes in promotion, salary and goal achievement (Arokiaswamy et al. 2011 qtd. in Hassan et al. 2017:5).

\subsection{Research Methods}

\section{The Context of the Survey}

The research was conducted at the University of Novi Sad, founded in 1960 as the second largest university in the Republic of Serbia. It is a non-integrated university, made up of 14 independent faculties operating as independent legal entities and two scientific research centres.

Considering the topic of our research it is important to highlight the position of women in the academic community. First, there are few women in top and mid level leadership positions (chancellor, vice chancellor, dean), even though we often find women leading large research programmes financed by the state (Savić 2015:10). Also, there are significant gender disparities in various scientific disciplines, some being more open to women: medical, 
technological and natural sciences, whilst others are less so: civil engineering, electrical engineering etc (Savić 2015:7).

\subsection{The Subject and the Aim of the Research}

The subject of our research is identifying the causes of women's (under)representation in leadership positions at our university. The focus is placed on mentoring and networking seen as important factors influencing the career advancement of women and their access to leadership positions at the university.

The research objectives are as follows:

1. Analysing the present gender (im)balance in leadership positions in different sciences (STEM, Social Sciences and Medicine) and in the academic hierarchy.

2. Analysing the influence of mentorship and networking and the challenges they pose for women in their career development and their access to leadership positions.

Based on the aim and objectives of the research we have asked the following research questions:

1. What is the statistical representation of women and men in leadership positions at the University considering various scientific disciplines and the academic hierarchy?

2. How do women academics perceive mentoring and networking both as opportunities and challenges in accessing leadership positions?

\subsection{Data Collection}

With a view to answering the research question "What is the statistical representation of women and men in leadership positions in the University considering various scientific disciplines and the academic hierarchy?", we have gathered and analysed statistical data on the gender structure of the teaching staff for the academic year 2014/2015 and top or mid level leadership positions: (deans) for the years 2013-2016, vice-deans for 2014/2015 and heads of departments for 2014/2015.

Concerning the second research question - women's views on mentoring and networking as opportunities/challenges/barriers to reaching leadership positions - we have applied qualitative data gathering and analysis - the semi structured interview that enabled us to better understand the perceptions of the interviewees about their experiences with the stated issue (Saunders, Lewis and Thornhill qtd. in Abalkhail and Allan 2015:158). This approach enabled us not only to focus on the interpretation of the significance of their experience in the workplace but also to hear the voice of women (Tlaiss 2013:7). We have analysed the data 
gathered with the qualitative method - content analysis with the basic unit being the interview (Lacey and Luff 2009:31). The semi structured interview, tailored to the needs of our research, covered the questions relating to the social and demographic characteristics of the interviewees and to their views on mentoring and networking as opportunities/barriers to reaching leadership positions. The majority of questions in the interview were open ended and their sequencing reflected the key topics.

The sample was made up of twenty (20) women professors, the age range being 40-65, three deans, 12 vice-deans and 5 heads of departments (16 professors and 4 associate professors). According to their marital and family status sixteen interviewees are married and four are single. The same ratio keeps in relation to children, sixteen of them have children and four do not. Ten interviewees come from STEM areas, seven from Social sciences and three from Medicine. Selection of the interviewees was based on the leadership positions held at the University, on the different experiences they had in those leadership positions and on their willingness to participate in the research.

Twenty (20) semi structured interviews were conducted over a period of one year (20152016), recorded on a digital voice recorder with an average duration of 45 minutes for each. Interviews were conducted in the mother language of the interviewees (Serbian) and for this paper their excerpts have been translated into English. Interviews were conducted individually at a place and time that suited interviewees. Before the start of the interview the interviewees were informed about the purpose of the research and they were reassured that the interview would remain confidential and anonymous. Subsequently, all interviews were transcribed.

\subsection{Data Analysis, Findings and Discussion}

For the gender balance analysis of the teaching staff at the University we have used data for 2014/2015 provided by the University. If we look at the gender structure of the total number of teaching staff at the University we note that the differences in the representation of men and women are not prominent. Data show that men hold around 52\% of the total teaching positions and women around $48 \%$.

Considering the scientific disciplines next, the gender balance of the teaching staff (professors and associates) at the University, data for 2014/2015 (see Chart 1), show that women are better represented in five faculties (Faculty of Philosophy, Faculty of Technology, Faculty of Medicine, Faculty of Sciences and Hungarian Language Teacher Training Faculty) that fall under all three scientific disciplines. This illustrates the process of feminization of disciplines in natural sciences (biology, chemistry and mathematics). There is also a possibility 
that women are employed as a secondary work force to fill in the places men are no longer interested in (Blagojević 2008:22). All together, women are underrepresented in five faculties (Faculty of Agriculture, Faculty of Law, Faculty of Technology, Faculty of Sport and Physical Education and Faculty of Civil Engineering) of which three are STEM areas and two are social sciences. A possible explanation is that "women are pushed out or not allowed in" those areas that are of high value, in other words, those that men are most interested in (Blagojević, 2008:22-24). The gender balance of teaching staff is present in four faculties (Faculty of Education, Academy of Arts, Faculty of Economics and "Mihajlo Pupin" Technical Faculty). A possible reason for this trend can be found in the statements above.

\section{Chart 1 Gender structure of teaching staff at the faculties of the University of Novi} Sad (2014/15).

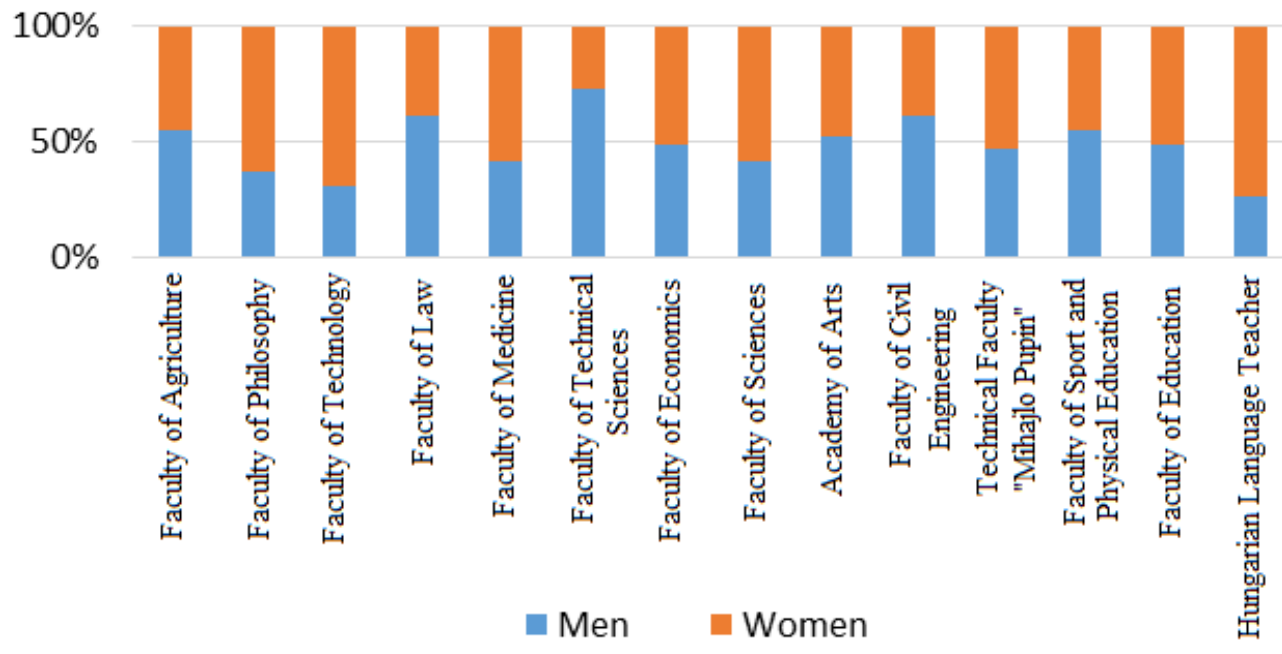

When it comes to individual academic ranks and gender balance (full professors, associate professors and assistant professors) at the University for 2014/2015, data show that women are better represented as professors in two faculties (Faculty of Technology and Hungarian Language Teacher Training Faculty) while men form the majority in eleven (11) faculties. Gender balance in the rank of full professors is achieved only in the Faculty of Philosophy (see Chart 2a).

Chart 2a Gender structure of teaching staff based on academic rank - professor and scientific disciplines at the University of Novi Sad for 2014/2015. 


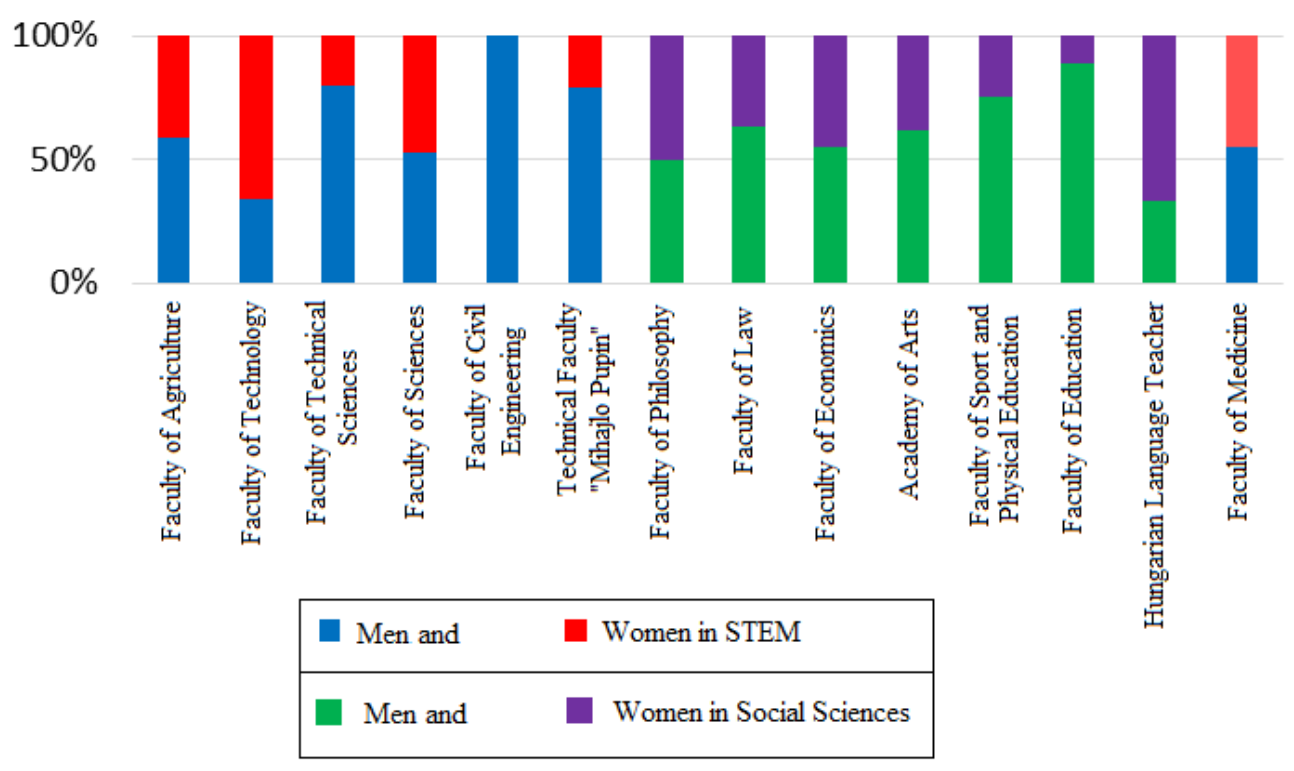

As associate professors women form the majority in seven faculties (Faculty of Philosophy, Faculty of Technology, Faculty of Medicine, Faculty of Sciences, Faculty of Sport and Physical Education, Faculty of Education and Hungarian Language Teacher Training Faculty) while men form the majority in six (Faculty of Agriculture, Academy of Arts, Faculty of Technical Sciences, Faculty of Law, Faculty of Economics and Faculty of Civil Engineering). Gender balance for the rank of associate professor is only achieved in the “Mihajlo Pupin” Technical Faculty in Zrenjanin (see Chart 2b).

Chart 2b Gender structure of teaching staff based on academic rank - associate professor and scientific disciplines at University of Novi Sad for 2014/2015.

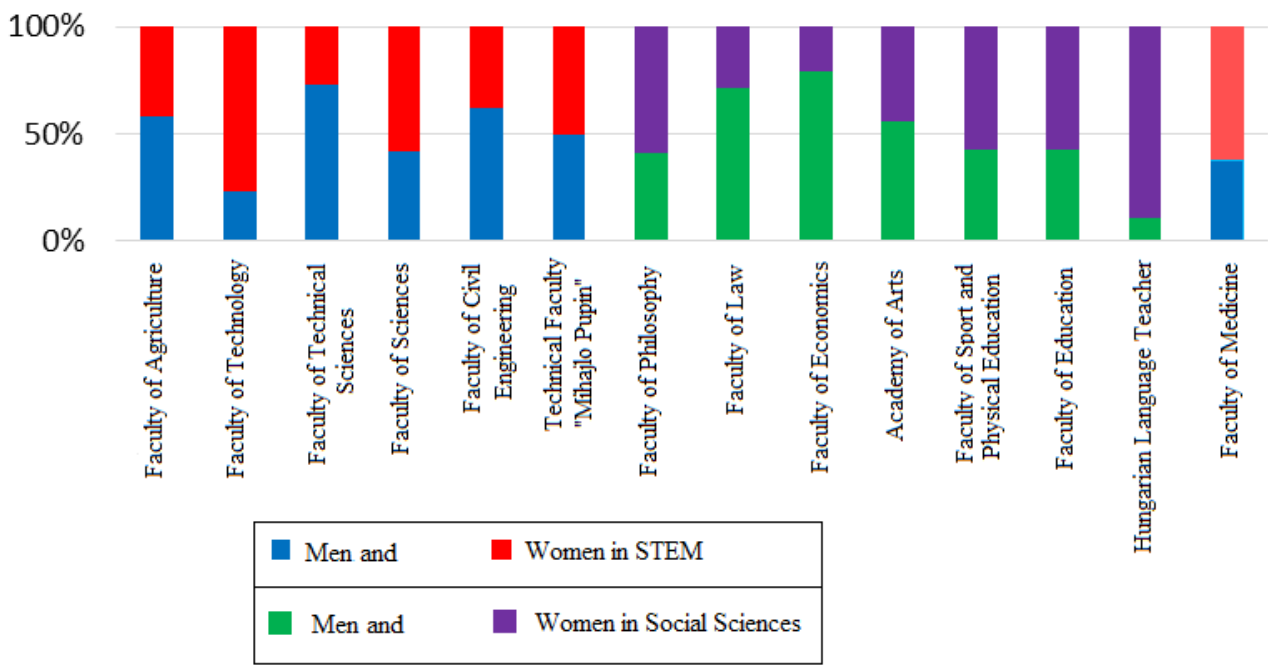


Women make up the majority of assistant professors in nine faculties (Faculty of Philosophy, Faculty of Technology, Faculty of Medicine, Faculty of Sciences, Academy of Arts, "Mihajlo Pupin" Technical Faculty, Faculty of Sport and Physical Education, Faculty of Education and Hungarian Language Teacher Training Faculty), while men are the majority in five faculties (Faculty of Agriculture, Faculty of Technical Sciences, Faculty of Civil Engineering and Faculty of Economics). Gender balance is achieved in the Faculty of Law (see Chart 2c).

Chart 2c Gender structure of teaching staff based on academic rank - assistant professor and scientific disciplines at the University of Novi Sad for (2014/2015).

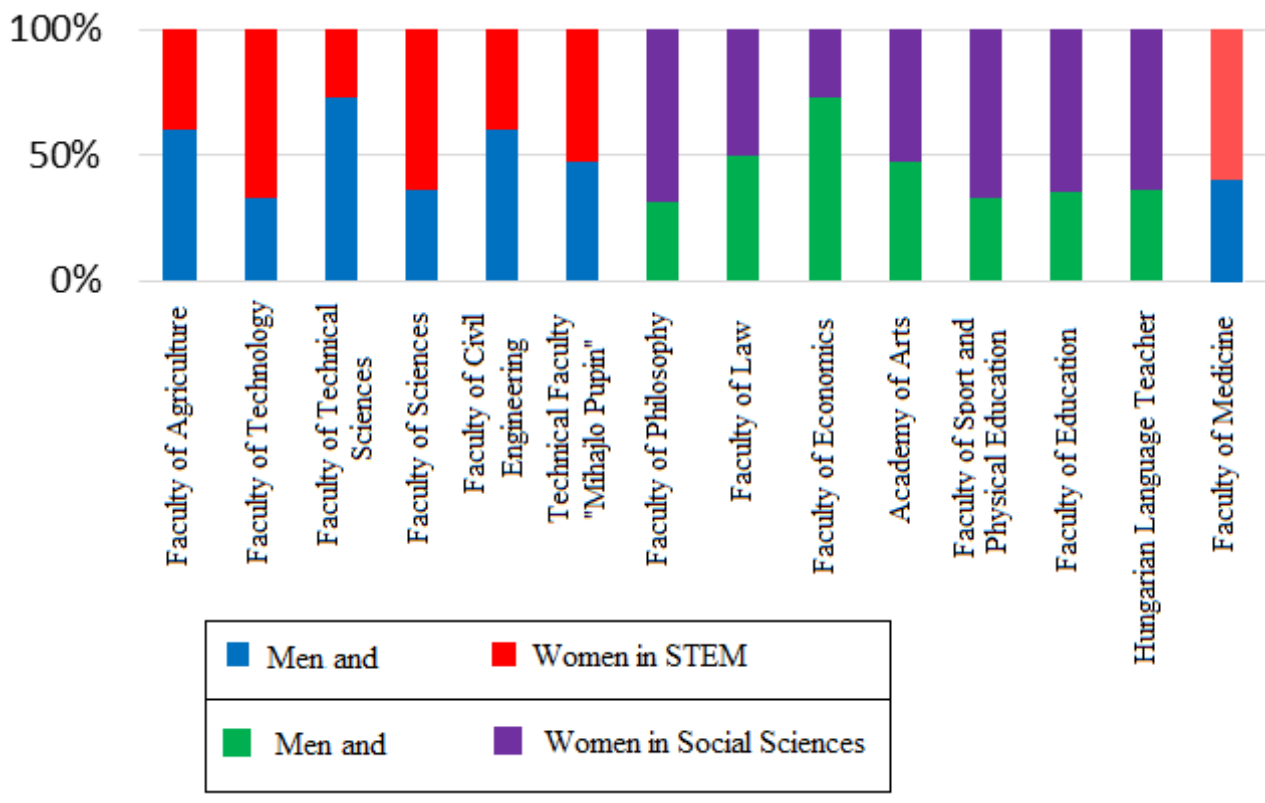

Summarizing the data in charts $2 \mathrm{a}, 2 \mathrm{~b}$ and $2 \mathrm{c}$ for $2014 / 15$ we can notice that women are underrepresented in the academic ranks of professor and associate professor. It further shows that as the academic rank rises in seniority the number of women is reduced, in other words career advancement of women is slower. One of the important criteria for promotion to senior academic ranks is the number of published papers in scientific journals and participation in research projects. According to some research (Frank Fox 2005; Frank Fox et al. 2011; Leahey 2006) women are mostly present in the activities related to teaching and mentoring students, while men are more focused on publishing scientific papers in high impact factor journals and participation in research projects. It is possible to assume men have more time available for research projects and writing articles while women find constraints placed on their time since they have to juggle professional and family obligations. Data on the gender structure of assistant 
professors show women hold these ranks in high percentage, suggesting that over the past few decades the number of women entering the academe has been on the increase.

Underrepresentation of women as deans is clearly reflected by the fact that in the period 2013-2016 only three women held the position (Faculty of Sciences, Faculty of Philosophy and Hungarian Language Teacher Training Faculty).

If we observe the gender structure of vice deans in 2014/2015, underrepresentation of women continues. The absence of women is evident in four faculties (Faculty of Agriculture, Faculty of Technical Sciences, Faculty of Civil Engineering and Hungarian Language Teacher Training Faculty). Men form the majority of vice deans in six faculties (Faculty of Law, Faculty of Medicine, Faculty of Economics, "Mihajlo Pupin” Technical Faculty”, Faculty of Sport and Physical Education and Faculty of Education). Only three faculties have a noticeable majority of women vice deans (Faculty of Philosophy, Faculty of Technology, and Faculty of Sciences). Gender balance is achieved only in the Academy of Arts (see Chart 3).

\section{Chart 3 Gender balance of vice deans at the University of Novi Sad (2014/2015)}

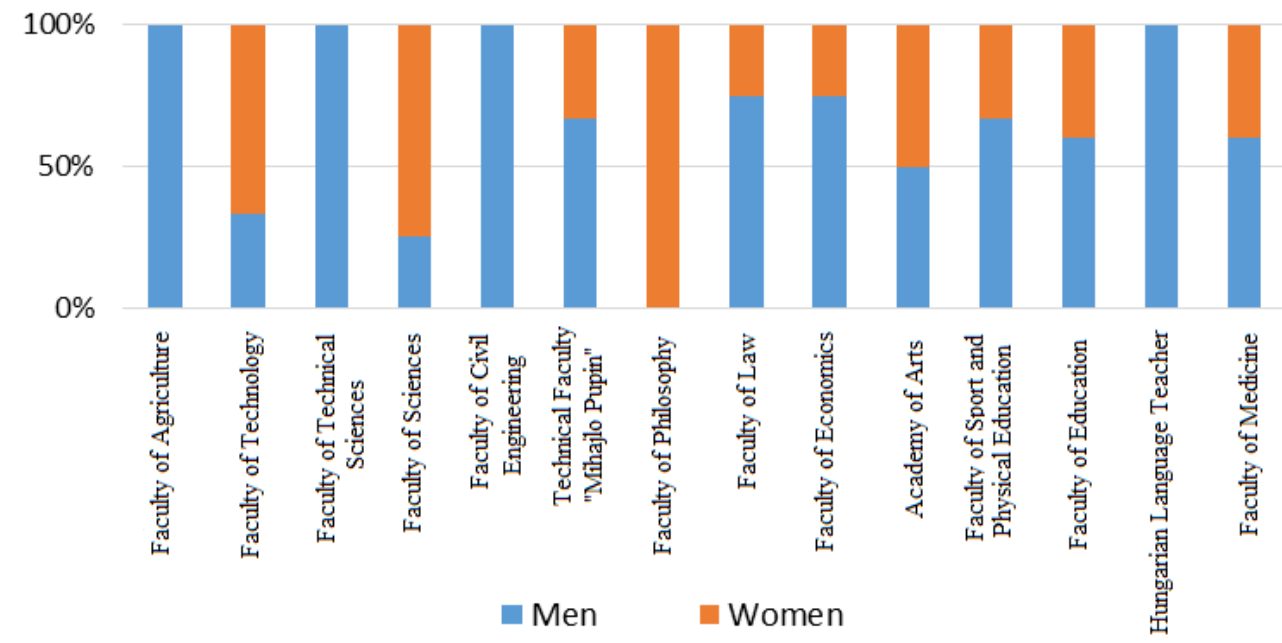

Based on the presented data, we can conclude that, although there has been a noticeable increase in the number of women among assistant professors, women are still underrepresented in the senior ranks of full professor and associate professor. Holding a higher rank is one of the formal requirements for university staff to become eligible for the position of deans and vice deans. Furthermore, even though there are no gender differences in terms of academic capital, women, compared to men, need greater support in networking and lobbying to be able to reach leadership positions (Markov 2006:266). As vice deans women are again underrepresented. They perform significant organizational tasks and yet they still do not hold any real power. "The authority of the vice deans is not organic, which hampers their chances to play an adequate role in power-sharing in the faculty" (Petrušić qtd. in Savić 2015:10). 
When we look at the data concerning the heads of departments for $2014 / 2015$, it is obvious that men represent the majority in five faculties (Faculty of Law, Faculty of Economics, Academy of Arts, "Mihajlo Pupin" Technical Faculty and Faculty of Education) whereas women act as heads of departments in four (Faculty of Philosophy, Faculty of Technology, Faculty of Medicine and Hungarian Language Teacher Training Faculty). We can especially note the total absence of women in three faculties (Faculty of Technical Sciences, Faculty of Sciences and Faculty of Civil Engineering). Gender balance is achieved in two faculties only (Faculty of Sport and Physical Education and Faculty of Agriculture). (see Chart 4).

\section{Chart 4 Gender balance of the heads of departments at the University of Novi Sad} (2014/15).

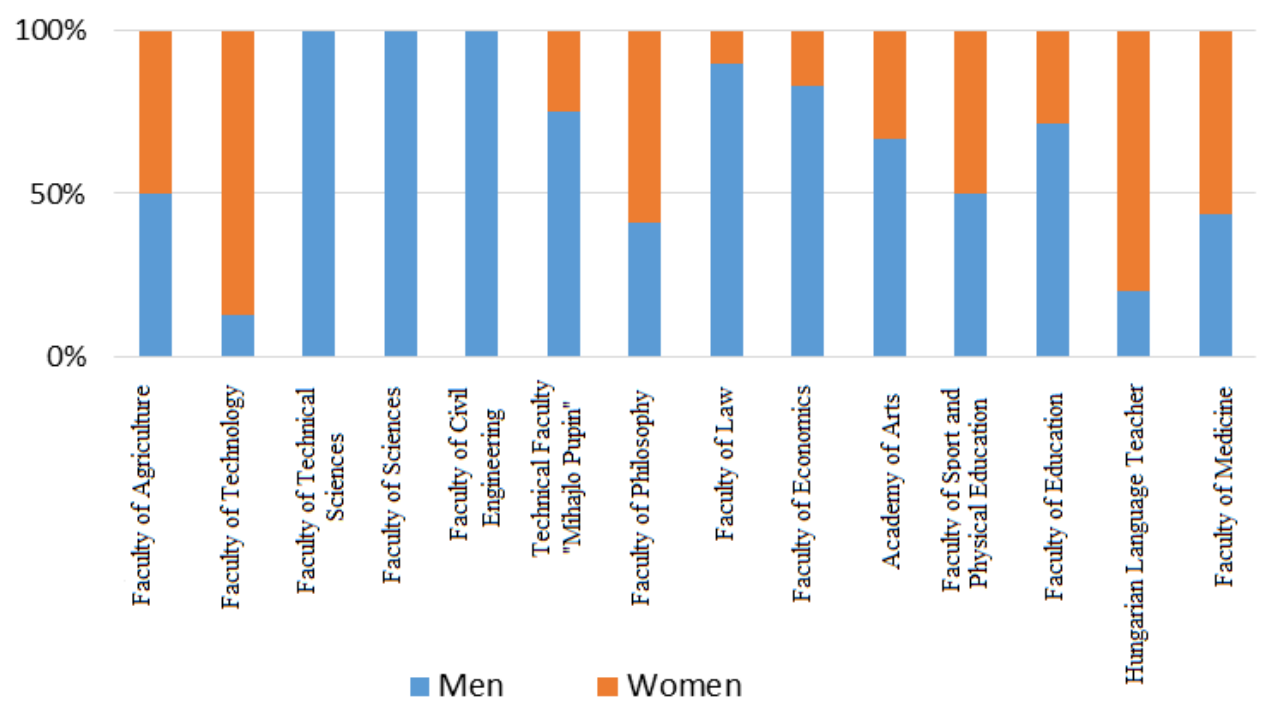

Data also point toward underrepresentation of women in the mid level management positions. Our research shows that men hold the majority of these positions, often nurturing the ambition of advancing to senior leadership positions at the University. This finding makes us wonder about the position of women in the academic environment from the perspective of power. If the position of the head of department is an important stepping stone to senior leadership positions, and we can note that few women hold this position, we have to ask ourselves how power works in the academic context. As it is evident that women are at a disadvantage when it comes to power sharing at the University, this question raises the necessity of an in-depth analysis of the possibilities of change in this area.

\subsection{Experiences of Women Professors in Mentoring and Networking in the Process of Reaching Leadership Positions}


Qualitative analysis of the data collected from the interviews with women professors confirms the existence of obstacles for women in reaching leadership positions (mentioned in the literature overview) and also enables deeper insight into their experiences in mentoring and networking, for example, how they handled obstacles in their leadership career path. Analysis also indicates several other aspects that exerted influence on their leadership career (overtime work that has a marked negative effect on private life; the University is very reluctant to accept leaders from other segments of society; previous leadership experience is of great importance; men-only networks exert greater influence in the selection process not only for leadership positions but also for access to senior academic ranks).

Most of the interviewees remarked that they did not have a formally appointed mentor which represented a significant obstacle for them in reaching a leadership position. Some new data that surfaced during interview analysis was that lack of a mentor presented a significant obstacle for the interviewees even after they had reached a leadership position, particularly during the initial period when they were still settling into the new position. Most of them had to manage their new leadership role on their own and only with the assistance of the University support services. Some of the interviewees remarked that they received significant support from informal mentors, mostly peers and persons who previously held leadership position at the University, but also outside it:

I did not have a mentor. I received support mostly from the people outside the University as I came from another profession. It was hard, especially at the beginning when I became a leader. It took me some time to understand how the University works. It is very difficult for University people to accept someone from the outside; they prefer to see someone from their own ranks take a leadership position. Fortunately for me, my previous leadership position helped me a lot. (Interviewee D).

I did not have a mentor. I did receive some support from the colleague who held that position before me but only when I specifically asked for it. I had to cope with a huge job, education reform was in full swing and I needed support. I sought advice form colleagues who were in the same situation. It would have been much easier for me if I had had a close colleague with experience to guide me. Fortunately, I was able to manage somehow. It took a lot of overtime work and as a consequence my private life suffered." (Interviewee G.).

I did not have a mentor. I managed on my own and it took a lot of time to understand how everything works. I had to consult the support services at the University very often. Most importantly I had the support of my colleagues. (Interviewee B.). 
Foremost I had the support of my friends. I valued very much the support of my colleagues from the department since they knew me and my work. I had no one to guide me through all the aspects of the job. I managed on my own, asking the University support services, working overtime. (Interviewee M).

I did not have a formal mentor but was fortunate to know people who held leadership positions before and I took any suggestion I could get from them. (Interviewee K.)

I did not have a mentor to help me, before or after reaching the leadership position. It was hard work. I was reading all the University rules and regulations on my own and just took all the work in my stride. I had to rely on University services for help, I had no one else to ask. (Interviewee Z).

I did not have a formal mentor when I took over the function, which was another obstacle in my work. I can say that the deal breaker for me to accept the job was the fact that both the dean and vice dean were women who supported me and helped me unselfishly not only during the process of appointment but also at the beginning of my leadership career. (Interviewee DI).

Interviewees mostly highlighted the importance of networking in reaching leadership positions as well as the necessity of forming women's networks. They also stressed that networking provides emotional and psychological support for women, it has a positive effect on leadership and is one of the non-objective criteria in the selection process. The importance of networks becomes particularly relevant with regard to senior leadership positions at the University, as interviewees explain:

They [networks] always have a strong influence. People would rather choose someone they used to sit with in the office, they know how that person thinks in comparison to someone they see for the first time during the interview for the job or after just reading their $\mathrm{CV}$. I have to note here that women networks are especially important, even though they often do not have much power. There is an informal network in Novi Sad that meets once a month which consists of women from different professions. These meetings are important because they enable women to test new ideas or exchange views, give suggestions to each other, etc. (Interviewee D.)

I think informal networks do not have a direct influence on the promotion of a person to a leadership position. They do have an impact on the academic career advancement especially if a person wished to climb higher in the hierarchy. I think they are especially connected with effective leadership in the academic context. In my opinion, the interpersonal skills of a leader are also important. (Interviewee J.)

I think women depend on networking more than men since men already hold the majority of leadership positions. Women are reaching out more for emotional and psychological support. (Interviewee V.) 
Networking is used by both men and women, but everyone tends to hold to their networks which is logical considering communication needs, how people work, what their priorities are; it helps them to achieve better understanding. Unfortunately, informal networks exert too much of an influence on the selection of candidates not only for leadership positions but also for promotion. Often candidates are judged by non-objective criteria and since most of the leaders are men it is natural that their groups have greater influence and most often choose men for leadership positions. (Interviewee Z.)

Networking is important in general, and especially important if you are trying to be a candidate in an environment where people did not know you beforehand. It is also important as you advance in the University hierarchy. (Interviewee K.).

\section{Conclusions}

In the last two decades in the context of European integration, the Republic of Serbia has given due attention to creating and implementing different documents and policies on gender equality with the aim of mainstreaming their principles. Despite the established legal and institutional framework, these principles are not acknowledged in real life, gender imbalance being reinforced and reproduced in different segments of the society. Our analysis shows that the trend of gender imbalance is still present in higher education, especially when we consider leadership positions. This paper examines the gender aspect of leadership focusing in particular on the question why women are underrepresented in leadership positions at the University.

The main findings of our research obtained through the analysis of gender (in)equality in leadership positions are:

- $\quad$ Gender differences in the teaching staff structure at the level of the University are not distinct;

- Underrepresentation of women in senior academic ranks (professor and associate professor) is plainly visible which points to the slower career development patterns for women in comparison with men;

- $\quad$ The gender structure of the academic rank of assistant professor reveals an increase in the number of women in nine faculties, indicating an increased interest in embarking upon an academic career;

- Data on the gender structure of leadership positions for deans in 2013/2016, vice deans in 2014/2015 and heads of departments in 2014/2015 reflect the underrepresentation of women in these ranks.

The main findings derived from the interviews point to the following: 
- Lack of formal mentoring for men and women, as a form of support for those with leadership potential;

- Necessity to organize mentoring programmes, especially for women with leadership potential;

- Existence of informal mentoring, mostly by peers, as a significant form of support in the process of reaching leadership positions;

- The strong role of the support services at the University, especially in the initial stage of a leadership career;

- Marked significance of previous leadership experience within or outside the University;

- Networking is very important in reaching leadership positions, especially for women;

- Creation of women academic networks is important as they foster development of suitable conditions and provide support for women with leadership potential;

- Networking is more significant for women as emotional and psychological support;

- It has a positive effect on leadership;

- It is often one of the non-objective criteria that has a strong influence in the selection for leadership positions;

- Networking grows in significance for the senior leadership positions at the University.

\section{Implications of the Study}

The theoretical importance of this research lies in its contribution to the theoretical and research corpus of knowledge related to gender aspects of leadership in higher education. One of the key questions is identifying the cause of underrepresentation of women in leadership positions at the university. Most of the studies centring on this problem have been conducted in the context of western countries, whereas our research project is one of the few relating to the social and cultural environment of Serbia.

The practical value of this research project resides in its attempt at incorporating gender equality principles in the strategies, policies, procedures and, hopefully, future gender equality plans at the University, creating a positive and stimulating space for women with leadership potential. Setting up special mentoring programmes with the aim of empowering women for leadership would be of further practical significance. 


\section{Limitations of the Study and Suggestions for Future Research}

The most evident limitation of the study is the relatively small sample it uses - only one university in Serbia, with its specific social and cultural context.

Considering all of the above, future research should incorporate several universities in Serbia, expand the sample to include men and conduct a comparative research with neighbouring countries which are European Union members.

\section{References:}

Abalkhail, Jouharah; Allan, Barbara. 2015. “Women's Career Advancement: Mentoring and Networking in Saudi Arabia and the UK" Human Resource Development International 18(2):153-168.

Acker, Joan. 2008. "Helpful Men and Feminist Support: More than Double Strangeness" Gender, Work and Organization 15(3):288-293.

Airini, Sunny Collings; Conner, Lindsey; McPherson, Kathryn; Midson, Brenda and Wilson, Cheryl. 2011. "Learning to Be Leaders in Higher Education: What Helps or Hinders Women's Advancement as Leaders in Universities" Educational Management Administration and Leadership 39(1):44-62.

Bagilhole, Barbara; Kate White. 2011. "Toward Interventions for Senior Women in Higher Education" in Gender, Power and Management: A Cross-Cultural Analysis of Higher Education. Barbara Bagilhole and Kate White (Eds.). Basingstoke: Palgrave Macmillan, pp.192-205.

Babović, Marija. 2016. Gender Equality Index for Serbia Measuring Gender Equality in 2014. Belgrade: Social Inclusion and Poverty Reduction Unit Government of Republic of Serbia.

Blackwood, Jothany; Sharon, Brown-Welty. 2011. "Mentoring and Interim Positions: Pathways to Leadership for Women of Color" in Women of Color in Higher Education: Changing Directions and New Perspectives (Diversity in Higher Education. Volume 10. Gaëtane Jean-Marie and Brenda Lloyd-Jones (Eds.). Emerald Group Publishing Limited, pp.109-133.

Benschop, Yvonne. 2009. "The Micro-politics of Gendering in Networking” Gender, Work and Organization 16 (2):217-37.

Blagojević, Marina.2008. "Scientific Excellence At the Semi-Periphery: Hierarchies, Exclusion and Possible Feminist Strategy for the Production of Knowledge" in Gender and Sciences: Proceedings of the Gender and Sciences, Sarajevo, 4-5 September. Jasminka Babić, Avdispahić, Jasna Bakšić-Muftić and Ugo Vlaisavljavić (Eds.). University of Sarajevo Center for interdisciplinary studies, pp:19-39.

Davidson, Marilyn; Ronald Burke. 2011. "Women in Management Worldwide: Progress and Prospect: An Overview" in Women in Management Worldwide: Progress and Prospects. Marilyn Davidson and Ronald Burke (Eds.). Farnham: Gower Publishing, pp.1-18.

De Vries, Jen; Claire, Webb. 2005. "Gender in Mentoring: A Focus on the Mentor; Evaluating 10 Years of a Mentoring Programme for Women". Paper presented at the 4th European Conference on Gender Equality in Higher Education, Oxford, UK, August 31-September 3.

Driscoll, Lisa G.; Parkes, Kelly. A.; Tilley-Lubbs, Gresilda. A., Brill Jennifer. M. and Pitts Banister, Vanessa. 2009. "Navigating the Lonely Sea: Peer Mentoring and Collaboration among Aspiring Women Scholars" Mentoring \& Tutoring: Partnership in Learning 17(1):5 -21. 
Durbin, Susan; Tomlinson, Jennifer. 2010. "Female Part-Time Managers: Networks and Career Mobility” Work, Employment and Society 24 (4):621-640.

Ismail, Maimunah; Rasdi, Roziah Mohd. 2007. "Impact of Networking on Career Development: Experience of High-Flying Women Academics in Malaysia” Human Resource Development International 10(2):153168.

Forret, Monica, L.; Dougherty, Thomas, W. 2004. "Networking Behaviors and Career Outcomes: Differences for Men and Women?” Journal of Organizational Behavior 25(3):419-437.

Frank Fox, Mary. 2005. “Gender, Family Characteristics, and Publication Productivity among Scientists” Social Studies of Science 35(1):31-50.

Frank Fox, Mary; Fonseca, Carolyn and Bao, Jinghui. 2011. "Work and Family Conflict in Academic Science: Patterns and Predictors among Women and Men in Research Universities” Social Studies of Science 41 (5):715-35

Hassan, Aabubakar Idris, Baharom, Mohd Nazri and Mutalib, Rozita, A. 2017. "Social Capital and Career Advancement of Female Academic Staff in Nigerian Universities” Journal of Management Development 36 (4):525-541.

Lacey, Anne; Luff, Donna. 2009. Qualitative Research Analysis. Yorkshire \& the Humber: The NIHR RDS for the East Midlands [Online]. Available: https://www.rds-yh.nihr.ac.uk/wpcontent/uploads/2013/05/9_Qualitative_Data_Analysis_Revision_2009.pdf [Accessed: 2017,September $10]$.

Leahey, Erin. 2006. “Gender Differences in Productivity Research Specialization as a Missing Link” Gender and Society 20(6):754-80.

Linehan, Margaret; Scullion, Hugh. 2001. "Networking for Female Managers' Career Development” Journal of Management Development 20(10):823-829.

Markov, Slobodanka. 2006. “Gender Inequalities within the Academic Elite” Gender Studies 5(1):54-268.

McDowall-Long, Kimberly. 2004. "Mentoring Relationships: Implications for Practitioners and Suggestions for and Suggestions for Future Research" Human Resource Development International 7f(4):519-534.

Pejatović, Aleksandra and Orlović-Lovren, Violeta. 2015. "Who is Who in Faculty Management in Serbia? A Concise Gender Analysis" in Contemporary Issues and Perspectives on Gender Research in Adult Education. Maja Maksimović, Joanna Ostrouch-Kamińska, Katarina Popović and Aleksandar Bulajić (Eds.). Belgrade: Institute for Pedagogy and Andragogy, Faculty of Philosophy, University of Belgrade \& Serbia ESREA, pp.115-129.

Pereira, Charmaine. 2007. Gender in the Making of the Nigerian University System. Ibadan, Nigeria: Heineman Educational Books.

Peters, April. L. 2011. "Black Women Faculty in Educational Leadership: Unpacking their Silence in Research" in Women of Color in Higher Education: Turbulent Past, Promising Future. Jean-Marie Gaetane and Brenda Lloyd-Jones (Eds.). Bingley, U.K.: Emerald Group Publishing Limited, pp.147-167.

Powell, Gary. N. 2010. Women \& Men in Management. 4th ed. London: Sage.

Prijić-Samardžija, Snježana, Avelini Holjevac Ivanka and Turk, Marko. 2009. "Women in Sciences: A Glass Ceiling” Društvena istraživanja 18 (6):1049-1073. 
Quinn, Jocey. 2012. Mentoring: Progressing Women's Careers in Higher Education. Equality Challenge Unit, London. UK [Online]. Available: http://www.ecu.ac.uk/wp-content/uploads/external/mentoringprogressing-womens-careers-in-higher-education.pdf [Accessed 2016, February 12].

Singh, Val; Vinnicombe, Susan and Kumra, Savita. 2006. "Women in Formal Corporate Networks: An Organisational Citizenship Perspective” Women in Management Review 21(6):458-82.

Statistical Office of the Republic of Serbia (2006-2013). 2014. Research on the Role of ICT-Related Knowledge and Women's Labour Market Situation. Belgrade: Statistical Office of the Republic of Serbia.

Savić, Svenka. 2015. Women Professors at the University of Novi Sad: Life Stories. Novi Sad: Futura Publications and Women Studies and Research.

Terhi, Nokkala; Ćulum, Bojana and Fumasoli, Tatiana. 2017. "Early Career Women in Academia: An Exploration of Networking Perceptions" in The Changing Role of Women in Higher Education. Heather Eggins (Ed.). Dordrecht: Springer, pp.267-290.

Tharenou, Phyillis. 2005. “Does Mentor Support Increase Women’s Career Advancement More than Men's? The Differential Effects of Career and Psychosocial Support.” Australian Journal of Management Vol. 30 (1):77-109.

Tlaiss, Hayfaa. 2013. "Entrepreneurial Motivations of Women: Evidence from the United Arab Emirates." International Small Business Journal 33(5):562-581.

Tonge, Jane. 2008. "Barriers to Networking for Women in a UK Professional Service." Gender in Management: An International Journal 23 (7):84-505.

UNDP United Nations Statistics Division. 2011. Statistics and Indicators on Women and Men. [Online]. Available: https://unstats.un.org/unsd/statcom/doc11/2011-4-SG-GenderStats-E.pdf [Accessed 2017, May, 15].

Vinnicombe, Susan et al. 2010. The Female FTSE Board Report 2010: Opening up the Appointment Process. International Centre for Women Leaders, Cranfield School of Management Cranfield, Bedford, England. [Online].

Available: https://dspace.lib.cranfield.ac.uk/bitstream/1826/4899/1/Female_FTSE_Report_2010.pdf [Accessed 2017, July 22].

Vrcelj, Sofija; Ermenc, Klara S. 2014. Je li (obrazovni) menadžment muški posao? Rijeka: Hrvatsko futurološko društvo.

Warner, Erica et al. 2016. "Faculty Promotion and Attrition: the Importance of Coauthor Network Reach at an Academic Medical Center.” Journal of General Internal Medicine 31(1):60-67. 